THE British government is to draw up ing party.

codes of practice for some experiments The question of potential hazards inirvolving the genetic manipulation of herent in the new techniques which microorganisms which could pose a allow DNA of different bacteria and potential hazard to workers and the viruses to be linked together and introgeneral public. Mr Fred Mulley, Sec- duced into other bacteria was conretary of State for Education and Science, in answer to a parliamentary question, announced the setting up of a working party which would

- draft a central code of practice and make recommendations for the establishment of a central advisory service for laboratories using the techniques available for such genetic manipulation, and for the provision of necessary training facilities.

- consider the practical aspects of applying in appropriate cases the controls advocated by the Working Party on the Laboratory Use of Dangerous Pathogens, chaired by Lord Godber, which reported earlier this year.

Mr Mulley also asked the Research Councils and others concerned not to proceed with work already identified as involving a potentially serious hazard, pending advice from the work-

\section{Government codes for gene manipulation}

\author{
by Eleanor Lawrence
}

siclered by the Working Party on the Experimental Manipulation of the Genetic Composition of Microorganisms, set up by the Advisory Board for the Research Councils and chaired by Lord Ashby. This committee, which reported in January of this year, came to the conclusion that such experiments should be permitted but only with certain safeguards.

These conditions include the use of experimental microorganisms which have been rendered relatively innocuous by specific mutations, and that certain types of experiment should be carried out under conditions of the strictest bacteriological security, in laboratories where the risk of escape to the outside or contamination of workers is minimised.

The definitive code of practice approved by the government, which the new working party should provide, will be welcome since it should end a period of delay and uncertainty which started a year ago with a call for a moratorium on a range of experiments by a committee of the National Academy of Sciences in the United States. At the same time the working party will be concerned with the practical aspects of implementing the findings of the Godber Committee which considered the use of proven pathogenic bacteria and viruses in laboratories throughout the UK. This committee drew up a list of organisms which could only be worked within conditions of strict security, which in the UK would confine such work to the few existing laboratories with suitable facilities.

\section{Shutting the GATE}

\section{by John Gribbin}

THE World Meteorological Organisation (WMO) has been stirred into issuing a formal denial that the GARP Atlantic Tropical Experiment (GATE), conducted last year by ten nations and probably the largest and most ccmplex international scientific experiment ever undertaken, was an experiment in hurricane control which adversely affected weather conditions in some countries.

The need for this denial stems, according to the WMO, from a statement made by "a professor of the
University of Mexico", and the WMO says that "it would indeed be regrettable if such unjustified statements were to detract from the acknowledged success of this international scientific research venture". Since the purpose of GATE was to monitor natural changes in the atmosphere and oceans, including large scale tropical disturbances, it would have been rather stupid of the investigators to attempt to alter the natural state of affairs, and most meteorologists are well aware of the need to understand natural changes in atmospheric processes before trying to induce changes by artificial means.

Perhaps the professor was confused by the inclusion of the word "experiment" in GATE's name which, al- though in the acronymous tradition of the WMO, is perhaps a slightly misleading title for an entirely observational project. But since Mexico was one of the participating countries, it should not have been too difficult for the critic to check his facts before issuing a public statement. The lesson to be drawn, perhaps, is that research into weather and climate is such a sensitive area that bodies such as the WMO should expect to be subject to the same intensive scrutiny as agencies responsible for nuclear research, or laboratories involved in genetic engineering.

In that case, perhaps GARP Atlantic Tropical Study might have been a happier choice of name.

\title{
correspondence
}

\section{PAC report:}

\section{a failure of communication}

THE Indian Public Accounts Committee report "Foreign Participation or Collaboration in Research Projects in India" (discussed in a leading article on July 3I) was critical of the Bombay Natural History Society, as well of the Research Unit for Genetic Control of Mosquitoes. In this letter, $\operatorname{Dr} A . N$. D. Nanavati, Secretary of the Bombay Natural History Society, considers some implications of the report.
The Public Accounts Committee (PAC) has expressed grave doubts about a number of research programmes carried out with foreign collaboration in India. Much of their alarm stems from the fact that the knowledge obtained from such researches can have applications in chemical and biological warfare $(\mathrm{CBW})$ and that the administrators examined by them did not seem to be fully aware of the fact. Based on this finding the committee has formed an opinion implied, though not explicitly stated, that those concerned in these projects were dupes, sometimes maybe even willing tools (in view of the relatively high salaries they received) in the hands of foreign organisations who wished to use India as an experimental arena for such studies.

I do not propose to go into the details or to try to refute the numerous misunderstandings and errors in the evidence on which these opinions were based. The facts of which I have personal knowledge, namely those connected with the Bombay Natural History Society (BNHS)-Migratory 
Animal Pathological Survey (MAPS) Bird Migration Study, have already been stated in your columns (November 29 1974) and, I believe, adequately answer every criticism voiced against the study originally by Dr Jayaraman, and later endorsed by the committee.

I need not repeat these arguments here except to point out that Dr Salim Ali's cri de coeur to Dr T. Ramachandra Rao, then the Director of the Virus Research Centre (VRC), Poona, requesting assistance for the studies on ectoparasites and blood smears of ringed birds has been completely misinterpreted. At the outset of the programme between the WHO and the BNHS, studies on this aspect were made by the VRC, Poona, and details of their findings were published from year to year in the Annual Reports of the VRC. When the WHO withdrew from the study, the VRC also withdrew, as it had no staff to spare for this work. Apart from occasional seasonal trips by the Institute of Natural Foci of Infectious Disease (NFID), Omsk for collection of such material (reports published in Russian), no other organisation came forward and this material remained unstudied until the MAPS organisation came on the scene. After the first year, they also requested that no more blood smears be sent as they were not in a position to study them. It was this lack of interest, and not any secret removal of data, which occasioned Dr Salim Ali's appeal to Dr Rao (who also found himself unable to help). These "orphan" blood smears are still with the society, awaiting a godfather to take an interest in them. There are several other misconceptions in the report, for example, the importance attached to Dr Theiler's suggested hypothesis on Yellow Fever epidemiology. This remains no more than a hypothesis, because it fails to explain all the observed phenomena. But these misconceptions are not of primary importance. What is important is that the PAC did not examine any scientist directly working on the projects, except Dr T. Ramachandra Rao, the officer on special duty, whose position was rather peculiar and is further discussed later. Had they examined the scientists, rather than the administrators and administrative scientists, who were only nominally concerned with the actual work on the projects, they might have revealed a completely different picture. In the case of the BNHS study, an examination of the facts will readily show that every working scientist was aware of the possible implications and repercussions, that the programme of work was formulated by the Indian Chief Investigator, and that adequate safeguards against secrecy were in force.

This brings us to the question of how far the administrator should be aware of the different facets and possibilities of any research study he is required to sanction. He must obviously rely on the opinions of his experts. Is it then incumbent on the experts concerned to appraise the administrator of all the various possibilities inherent in a proposed research study, and is such a procedure really necessary or relevant or even possible? When a project is being prepared with a particular object in mind, it is necessary to establish how far that the object will be met by the study. The expert has to advise on (a) the importance of the problem (so that it may be judged in proper perspective in the national contest), (b) the type of information which needs to be obtained to solve the problem and (c) the extent to which the proposed study can be expected to yield the required information. This is all the administrator needs to know to enable him to assess the project correctly and to judge its requirement in men and materials and its anticipated benefits relative to the many other demands which may be made on his resources. Anything else is irrelevant. Considerations like possible misuse of the knowledge gained, the safeguards necessary, and so on, must be the responsibility of the experts on the job. For example, a few years ago a study was made on the spread of cholera from village to village in West Bengal and the mechanisms by which the village wells got contaminated. Every student of medicine and microbiology knows that the understanding of such process can be used either for countering the spread of cholera or for its enhancement, that is for biological warfare using cholera germs. Yet, had the administrators concerned been questioned about that proiect they would not have shown any greater awareness of such dangers than in the present case.

The committee's conclusions lose much of their significance because they were not, in fact, based on the evidence necessary for a correct appreciation, the evidence of the scientists concerned on the job. The only working scientist examined was $\operatorname{Dr} \mathrm{T}$. Ramachandra Rao, who made it clear that knowledge is neutral and the only safeguard against misuse of knowledge is its free publication.

The committee's criticisms and apprehensions about the detailed programme and sequence of studies made by the Research Unit for Genetic Control of Mosquitoes may or may not be correct. It is impossible to say without questioning the scientists concerned, which has not been done. Dr Rao could not say much about the formulation of the programme because he came on the scene after this work had been done. (It may be noted in pass- ing that the remarks on the financial benefits supposed to have accrued to Dr Rao by joining the scheme are contradicted by the Indian Council of Medical Research (ICMR) letter, laying down the terms of Dr Rao's appointment.)

In spite of such errors and misconceptions, we must take due note of the fact that an independent body of men, representing all shades of opinion, has enquired into these projects and has found reasons for apprehension. Although some of these apprehensions may be exaggerated or based on incorrect evidence, there are others, not so prominently emphasised by the committee, which call for attention.

If we accept the proposition that the details of work, the implications of the study, and the safeguards against possible dangers are the responsibility of the expert concerned, it is also incumbent on the authorities to appoint proper and competent experts. Was this done? The committee has rightly pointed out that neither of the two individuals who occupied the office of the Director General of the ICMR (Indian counterpart of the Project Director) was qualified to judge the intricacies of entomological research. This was a serious lapse and though it was soon remedied, by the appointment of an eminent entomologist, Dr T. R. Rao, as an officer on special duty, such an appointment should have been made before any programmes were decided on. This delay may, as the Press Trust of India correspondent claimed. have involved us in programmes of dubious value. Whether this was or was not the case could not be ascertained from the evidence available. But that such a possibility existed is indicative of our failure to maintain adequate vigilance; this is the real danger which needs to be highlighted.

Unfortunately, the defect is a part of a larger malaise, and calls for examination of the defects in our methods of recruitment and appointment which leave a substantial proportion of our most brilliant men and women unemployed, so that they must seek opportunities for work in other countries. And what of our habit of vesting all authoritv in a top official irrespective of qualifications? But consideration of these points would not be strictly relevant to the issues raised in this report, however important they may be in creating such potentially dangerous situations.

It is unfortunate that although the committee has made sincere efforts to examine the issues involved, its conclusions are invalid because of a lack of appreciation of the distinction between the role of the administrator and that of the scientist in research projects. 